\title{
KONTRIBUSI PELAKSANAAN FUNGSI KEPEMIMPINAN KEPALA MADRASAH DAN IKLIM ORGANISASI TERHADAP KINERJA GURU MTSN DI KABUPATEN SOLOK
}

\author{
Livia Susanti \\ Guru MTSN Koto Baru Solok, \\ Koresponden: Asam J a o Indah Blok B.04 Koto Baru Solok \\ e-mail : Liviasusanti_054@gmail.com HP. 081374228671
}

\begin{abstract}
This Thesis discusses the contribution of the implementation of leadership function of the Madrasah organization atmosphere toward work performance of MTs $N$ teachers in Solok. The research is categorized as expost facto by using quantitative with correlational research as its approach. This research took all the teachers of the MTsN in Solok as the samples. In totalthere were 193 persons and 78 of them were selected as the research samples by means of stratified proportional random sampling technic. The collected data used questionaire instrument by using Likert scale. The first and second hypothesis were tested by using correlation technique and simple regression. Meanwhile, the third hypothesis was tested by using double regression. The result of the data analysis concludes that : (1) The implementation of the leadership function of the Madrasah Headmaster contributes significantly $46.8 \%$ towards work performance of the teachers of the MTsN in Solok, (2) organization atmosphere contributes significantly $57.7 \%$ towards work performance of the teachers of the MTsN in Solok, (3) the implementation of the leadership function of the Madrasah Headmaster and organization atmosphere contribute significantly $63.3 \%$ to the work performance of the MTsN teachers in Solok.
\end{abstract}

Key Words: Implementasi, fungsi kepemimpinan, iklim Organisasi, kinerja guru

\section{PENDAHULUAN}

Masalah kinerja bagi guru adalah masalah yang sangat penting. Tanpa adanya kinerja yang baik tidak mungkin madrasah dapat menghasilkan peserta didik yang kompetitif. Peningkatan kinerja mempunyai implikasi yang positif bagi madrasah itu sendiri, artinya madrasah dapat menghasilkan kuantitas dan kualitas peserta didik yang optimal. Kinerja guru akan meningkat bila didukung oleh penerapan sistem manajemen kinerja dan sistem pengembangan karir yang baik dan efektif. Bila system menajemen kerja sudah meningkat secara otomatis mutu pendidikan di madrasah tersebut juga akan meningkat.

Untuk memiliki kinerja yang baik guru hendaknya memiliki beberapa kompetensi yang akan digunakan dalam melaksanakan tugasnya sebagai seorang pendidik. Berdasarkan Peraturan Menteri Pendidikan Nasional Republik Indonesia Nomor 16 Tahun 2007 tentang Standar Kualifikasi Akademik dan Kompetensi Guru dijelaskan bahwa standar kompetensi guru dikembangkan secara utuh dari 4 kompetensi utama, yaitu: (1) kompetensi pedagogik, (2) kepribadian, (3) 
sosial, dan (4) profesional, Djama'an Satori dkk, (2008:24), Keempat kompetensi tersebut terintegrasi dalam kinerja guru.

Keterlibatan guru dalam aktivitas kerja penting untuk diperhatikan, sehingga mereka mau dan senang bekerja sama baik dengan pimpinan ataupun dengan sesama teman kerja. Salah satu cara yang dapat dipakai untuk mendorong keterlibatan guru adalah dengan mengajak partisipasi dan melakukan koordinasi dengan mereka dalam berbagai kesempatan pembuatan keputusan, yang dapat menumbuhkan keyakinan pada guru bahwa apa yang telah diputuskan merupakan keputusan bersama. Di samping itu, dengan melakukan hal tersebut, guru merasakan bahwa mereka diterima sebagai bagian yang utuh dari organisasi, dan konsekuensi lebih lanjut, guru merasa wajib untuk melaksanakan bersama apa yang telah diputuskan karena adanya rasa keterikatan dengan apa yang telah diciptakan bersama. Dengan demikian dapat diharapkan untuk lebih meningkatkan kinerja guru.

Sondang P. Siagian (2002:34) menjelaskan kinerja guru dipengaruhi oleh beberapa faktor antara lain intelegensi, sikap, kemampuan profesional, keterampilan menajemen, keamanan, suasana atau kerja tim, perencanaan, kepemimpinan dan pengawasan. Faktorfaktor tersebut sebagaimana dikemukakan oleh Siagian bahwa ada beberapa faktor yang dapat mempengaruhi kinerja antara lain : (1) Intelegensi, (2) Sikap, (3) Kemampuan professional guru, (4) Ketrampilan menajemen, (5) Suasana atau iklim kerja , (6) Keamanan dan perlindungan kerja, (7)
Perencanaan, (8) Pengawasan, (9) Motivasi internal, (10) kepemimpinan kepala sekolah. Senada dengan pendapat Amstrong (1998:16-17) bahwa faktor-faktor yang mempengaruhi kinerja adalah:

1. Faktor individu (personal factors). Faktor indiidu berkaitan dengan keahlian, motivasi, komitmen, dll.

2. Faktor kepemimpinan (leadership factors). Faktor kepemimpinan berkaitan dengan kualitas dukungan dan pengarahan yang diberikan oleh pimpinan, manajer, atau ketua kelompok kerja.

3. Faktor kelompok atau rekan kerja (team factors), berkaitan dengan kualitas dukungan yang diberikan oleh rekan kerja.

4. Faktor sistem (system factors), berkaitan dengan sistem/metode kerja yang ada dan fasilitas yang disediakan oleh organisasi.

5. Faktor situasi (contextual/situational factors), berkaitan dengan tekanan dan perubahan lingkungan, baik lingkungan internal maupun eksternal.

Faktor-faktor yang mempengaruhi kinerja guru ini perlu mendapat perhatian serius dari pimpinan organisasi dalam hal ini kepala madrasah jika guru diharapkan dapat memberikan kontribusi yang optimal. Kepala madrasah sebagai pemimpin lembaga pendidikan harus dapat mengembangkan dan menyalurkan kebebasan berfikir seluruh guru dan perangkat madrasah yang ada sehingga akan tercipta suasana kerja yang efektif dan efisien. Selain itu kepala madrasah juga harus dapat mendorong terjadinya persamaan 
pendapat dengan sikap saling menghargai dalam menyelesaikan tugas-tugas yang berkaitan dengan saling menghormati dalam menyelesaikan tugas-tugas yang berkaitan dengan kemajuan lembaga pendidikan.

Berdasarkan observasi awal yang penulis lakukan di lapangan, maka penulis dapat mengidentifikasi permasalahan tentang kinerja guru MTsN di Kabupaten Solok, yaitu masih adanya budaya datang ke sekolah hanya pada jam mengajar, sering terjadi proses pembelajaran tidak tepat waktu, seperti lambat memulai pembelajaran dan lebih cepat mengakhiri pembelajaran, guru mengumpulkan perangkat pembelajaran sering tidak tepat waktu, perangkat pembelajaran hanya sebatas memenuhi kewajiban rutinitas tahunan yang kemudian tidak dipergunakan menurut semestinya. Sering terjadi keluhan- keluhan bagi guru diawal tahun ajaran karena aturan yang kaku tentang perangkat mengajar. Adanya guru yang lambat dalam mengumpulkan nilai sehingga memperlambat proses penyusunan laporan hasil belajar siswa, adanya guru yang melaksanakan program remedial tidak sesuai dengan aturan pembelajaran.

Di sisi lain masih ditemukan sebagian guru yang kurang mampu melakukan pengelolaan kelas dengan baik, hal ini teramati ketika dilakukan kunjungan kelas langsung terhadap beberapa guru yang sedang mengajar di kelas, masih ditemui suasana kelas yang kurang kondisif seperti suasana gaduh, siswa masih ngobrol sesamanya, dan lain sebagainya, sehingga proses belajar mengajar tidak berjalan sebagaimana mestiya.
Banyak persoalan yang berhubungan dengan mutu pendidikan sebagai salah satu indikasi kinerja guru. Dalam suatu lembaga pendidikan sering ditemui kesenjangan dan tidak terbinanya suasana dan hubungan yang harmonis sesama guru dan antara guru dengan karyawan, ataupun dengan kepala madrasah. Dalam situasi yang demikian ditemui beragam gambaran tentang kinerja guru, ada guru yang selalu menampilkan kinerja yang baik seolaholah tidak terpengaruh oleh kondisi apapun, namun di sisi lain ditemui masih ada guru yang belum berkinerja baik.

\section{METODE PENELITIAN}

Tempat penelitian ini adalah MTsN di Kabupaten Solok. Waktu penelitian bulan Oktober s/d November 2013.

Populasi penelitian ini adalah semua guru MTsN di Kabupaten Solok yang telah menjadi Pegawai Negeri Sipil (PNS) yang aktif mengajar pada tahun 2013/2014. jumlah populasi sebanyak 193 orang. Populasi tersebut dikelompokkan berdasarkan strata pendidikandan masa dinas.Sampel penelitian ini dipilih dengan menggunakan teknik stratified proportional random sampling. Sampel diambil berdasarkan masa kerja yaitu78 orang,proses pengambilan sampel dilakukan secara acak darisetiap strata dengan memberi nomor pada setiap responden. Nomor yang terpilih dijadikan sebagai sampel dan jumlahresponden untuk setiap sel dari setiap strata dilakukan secaraproposional (berimbang). 


\section{PEMBAHASAN}

Data variabel kinerja guruMTsN di Kabupaten Solok diperoleh dari 36 butir pernyataan. Idealnya skor variabel kinerja guru MTsN di Kabupaten Solok menyebar antara 118 (terendah) dan 180 (tertinggi). Selanjutnya diperoleh skor rata-rata (mean) sebesar skor rata-rata 157.78 median 162 , modus 174 dan simpangan baku 16.461. Tingkat pencapaian skor Kinerja Guru adalah hasil bagi rata-rata dengan skor maksimum ideal yaitu $157.78 / 180=0,88$ atau $88 \%$ (termasuk kategori baik). Hasil ini menunjukkan bahwa kinerja guru di MTsN tersebut baik.

Beberapa hal yang penulis pandang mempengaruhi kondisi ini adanya upaya peningkatan kualitas tenaga pendidik dalam lima tahun terakhir yang memperlihatkan frekuensi tinggi, baik yang dilakukan oleh Kementerian Agama dan Depdiknas maupun Dinas Pendidikan di daerah. Upaya -upaya yang dilakukan terhadap terhadap guru tersebut antara lain berupa :

a. Perekrutan guru baru (MTsN khususnya) yang mensyaratkan berpendidikan $S 1$, dan peningkatan pendidikan guru yang masih berpendidikan D3 ke jenjang pendidikan S.1, jenjang pendidikan S.1 ke jenjang pendidikan S.2 diberbagai Perguruan Tinggi. Sehingga memungkinkan kinerja mengajarnya pun akan lebih baik.

b. Program sertifikasi guru dengan segala hak dan kewajibannya telah memberikan harapan kepada guru sebagai insentif yang mendorong kinerja mengajar guru kearah yang lebih baik. Insentif sendiri dalam artian psikologi adalah penghargaan, yang tidak saja berupa upah, gaji, dan tunjangan, tetapi juga hal yang tidak bersifat finansial, seperti kenaikan pangkat istimewa, bintang jasa atau penghargaan lainnya yang amat berperan dalam perilaku. Perilaku seseorang dalam bekerja merupakan serangkaian aktivitas-aktivitas pekerjaan yang menghasilkan kinerja.

Peningkatan kinerja guru MTsN di kabupaten Solok di masa yang akan datang akan dapat diharapkan lebih baik lagi melalui peningkatan pelaksanaan fungsi kepemimpinan kepala madrasah dalammenyiapkan peserta didik sebagai generasi yang memiliki sumber daya yang mampu menghadapi era kompetisi, sebagai manifestasi rasa tanggung jawab serta pengabdian para guru. Hal demikian tentunya diharapkan dapat berdampak positif terhadap peningkatan kualitas pembelajaran serta interaksi siswa dan guru dalam menangani berbagai persoalan pendidikan yang dihadapi saat ini.

Data variabel Pelaksanaan Fungsi Kepemimpinan Kepala Madrasah diperoleh dari 47 butir pernyataan. Idealnya skor variabel Pelaksanaan Fungsi Kepemimpinan Kepala Madrasah menyebar antara 115 (terendah) dan 235 (tertinggi). Selanjutnya diperoleh skor rata-rata (mean) sebesar 196,6 skor tengah (median) sebesar 199.5, skor yang banyak muncul (mode) 221 dan simpangan baku (standard deviation) 26.825. Tingkat pencapaian skor pelaksanaan fungsi kepala madrasah adalah hasil bagi rata-rata dengan skor maksimum ideal yaitu 196.6/235 $=0,83$ atau 83\% (termasuk kategori baik). Hasil 
ini menunjukkan bahwa pelaksanaan fungsi kepemimpinan kepala madrasah MTsN di Kabupaten Solok baik.

Pelaksanaan fungsi kepala Madrasah merupakan hal yang sangat penting dalam menjalankan proses belajar mengajar di sekolah, artinya semakin baik pelaksanaan fungsi kepemimpinan kepala madrasah maka semakin meningkat pula kinerja guru MTsN di kabupaten Solok, demikian sebaliknya, jika pelaksanaan fungsi kepemimpinan kepala madrasah menurun maka akan mengakibatkan menurunnya kinerja guru MTsN di kabupaten Solok.

Kepala madrasah harus dapat memberikan ketauladanan kepada semua warga madrasah, tidak bisa sekedar memiliki memiliki keinginan yang harus diikuti oleh bawahan, tanpa bisa menunjukkan ketauladanan bagi mereka. Dalam Islam antara ucapan dan perbuatan haruslah relevan. Bila seorang berani menyeru kepada orang lain untuk melakukan kebaikan, maka dia harus menjalankan seruan itu juga. Bahkan seharusnya praktek kebaikan dalam kehidupan sehari-hari lebih dahulu dilakukan sebelum dia menyeru orang lain untuk melalukannya. Sebab, orang-orang yang mendengar seruannya itu akan senantiasa akan memperhatikan orang yang menyeru kebaikan; apakah penyeru benar-benar mempraktekkan seruan itu yang berarti dia layak menyerukan dan layak diikuti, atau justru itu orang yang selalu mengingkari ucapannya sendiri. Bila kenyataan yang kedua ini terjadi, maka orang lain tidak akan mengikutinya. Sikap demikian ini dibenci oleh Allah, sebagaimana firman-Nya:

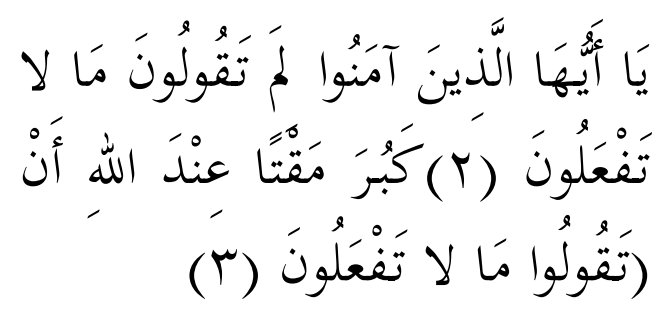

Artinya: "Wahai orang-orang yang beriman, kenapakah kamu mengatakan sesuatu yang tidak kamu kerjakan? Amat besar kebencian di sisi Allah bahwa kamu mengatakan apa-apa yang tidak kamu kerjakan”. (QS. 61 : 2-3).

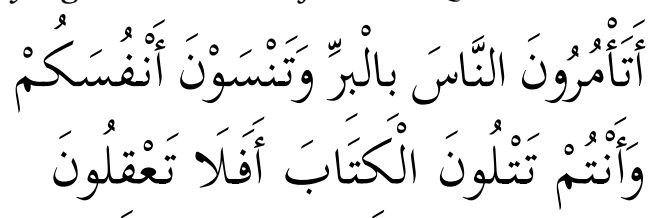

Artinya: "Mengapa kamu suruh orang lain (mengerjakan) kebaktian, sedang kamu melupakan diri (kewajiban) mu sendiri, padahal kamu membaca Al Kitab (Taurat)? Maka tidaklah kamu berpikir?" (QS 2:44)

\section{ANALISIS DATA}

Data variabel iklim organisasi diperoleh dari 43 butir pernyataan. Idealnya skor variabel Kepuasan Kerja Guru Sekolah Dasar Negeri se-Kecamatan Baso menyebar antara 119 (terendah) dan 214 (tertinggi). Selanjutnya diperoleh skor rata-rata (mean) sebesar 189,05, skor tengah (median) sebesar 193, skor yang banyak muncul (mode) 208 dan simpangan baku (standard deviation)21,516. Tingkat pencapaian responden pada variabel iklim organisasi adalah hasil bagi ratarata dengan skor maksimum ideal yaitu $177,6 / 215=82,6 \%$ (termasuk kategori baik). Hasil ini menunjukkan bahwa klim organisasi pada MTsN tersebut baik.

Peningkatan mutu pendidikan dapat dilakukan bila mendapat dukungan dari berbagai pihak. Salah satu faktor yang perlu 
mendapat perhatian untuk peningkatan mutu tersebut adalah iklim organisasi. iklim organisasi yang baik akan membuat guru menjadi betah dalam menjalankan tugas dan tanggung jawabnya. Iklim Organisasi berkontribusi pula terhadap kinerja guru, karena iklim Organisasi yang baik akan menimbulkan suasana yang menyenangkan dan rasa puas bagi guru dalam melaksanakan pekerjaan yang pada akhirnya akan berpengaruh terhadap kinerjanya. Iklim Organisasi yang baik akan menimbulkan suasana yang baik sesama guru, atau antara guru dengan kepala madrasah dan tenaga pendidik serta semua masyarakat yang terkait dengan proses pendidikan yang ada pada sebuah madrasah.

Dalam lembaga madarasah,kepala madrasah sebagai pimpinan harus memberikan perhatian secara sungguh-sungguh terhadap usaha-usaha mendayagunakan, memajukan dan meningkatkan kinerja guru di sekolah secara terus menerus. Orientasi dari pembinaan kepala madarsah ini diarahkan pada peningkatan kinerja guru yang meliputi: pertumbuhan keilmuan, wawasan berpikir, sikap terhadap pekerjaan dan keterampilan guru dalam melaksanakan tugasnya.

Seorang kepala madrasah harus dapat memberikan ketauladanan kepada semua warga madrasah. Bagi seorang manajer pendidikan Islam, seorang kepala madrasah tidak bisa sekedar memiliki keinginan yang harus diikuti oleh bawahan, tanpa bisa menunjukkan ketauladanan bagi mereka. Dalam Islam antara ucapan dan perbuatan haruslahtelevan. Bila seorang berani menyeru kepada orang lain untuk melakukan kebaikan, maka dia harus menjalankan seruan itu juga. Bahkan seharusnya praktek kebaikan dalam kehidupan sehari-hari lebih dahulu dilakukan sebelum dia menyeru orang lain untuk melalukannya. Sebab, orang-orang yang mendengar seruannya itu akan senantiasa akan memperhatikan orang yang menyeru kebaikan; apakah penyeru benar-benar mempraktekkan seruan itu yang berarti dia layak menyerukan dan layak diikuti, atau justru itu orang yang selalu meningkari ucapannya sendiri.

Data penelitian ini dianalisis dengan menggunakan rumus statistik korelasi dan regresi. Analisis dengan mengunakan teknik statistik ini dapat dilakukan hanya bila data yang akan dianalisis memenuhi beberapa persyaratan yaitu : (1) data masing masing variabel berdistribusi dengan normal, (2) data setiap kelompok (variabel) bersifat homogen, dan (3) garis regresi yang menghubungkan masing-masing variabel bebas dengan variabel terikat bersifat linear.

Pemeriksaan persyaratan analisis dilakukan dengan menggunakan bantuan program SPSS Versi 17.0. Dari hasil analisis dapat disimpulkan bahwa pelaksanaan fungsi kepemimpinan kepala madrasah $\left(\mathrm{X}_{1}\right)$ dan iklim organisasi $\left(\mathrm{X}_{2}\right)$ masing-masing memiliki hubungan linier dengan variabel kinerja gurur (Y) serta memenuhi kenormalan dan homogenitas data, karena itu semua persyaratan untuk penggunaan teknik statistik untuk pengujian hipotesis terpenuhi. 


\section{UJI HIPOTESIS}

Hipotesis pertama yang diajukan dalam penelitian ini adalah Terdapat kontribusi yang signifikan pelaksanaan fungsi kepemimpinan kepala Madrasah terhadap kinerja guru MTsN di Kabupten Solok, kontribusi sebesar 46,8\%. Dapat diartikan bahwa kinerja guru MTsN di kabupaten Solok sebesar 46,8\% ditentukan oleh pelaksanaan fungsi kepala Madrasah sisanya $53.2 \%$ ditentukan oleh faktor lain.

Hipotesis kedua adalah "terdapat kontribusi yang signifikan iklim orgnisasi terhadap kinerja gurur MTsN di Kabupaten Solok sebesar 57,3\%. Dengan demikian dapat diartikan bahwa kinerja guru MTsN di Kabupaten Solok sebesar $42.7 \%$ ditentukan oleh iklim organisasi kinerja guru, sisanya 42,7 $\%$ ditentukan oleh faktor lain.

Hipotesis ketiga adalah "terdapat kontribusi yang signifikan pelaksanaan fungsi kepemimpinan kepala madrasah dan iklim organisasi terhadap kinerja guru MTsN di kabupaten Solok sebesar 63,3\%, dapat diartikan bahwa kinerja guru MTsN di kabupaten Solok sebesar 63,3 \%. ditentukan oleh pelaksanaa fungsi keoala madrasah dan iklim organisasi sisanya $36.7 \%$ ditentukan oleh faktor lain yang tidak diteliti dalam penelitian ini.

Untuk mengetahui hubungan masingmasing variabel bebas tanpa adanya interaksi dari variabel bebas lain dengan vaiabel terikat, dilakukanlah analisis korelasi parsial. Hal ini dilakukan dengan mengontrol, dengan salah satu vaiabel bebas dengan vaiabel terikat. variabel $\mathrm{X}_{1}$ berhubungan dengan variabel $\mathrm{Y}$ pada saat variabel $\mathrm{X}_{2}$ dikontrol. Hal ini dibuktikan dengan koefisien korelasi sebesar 0.684 dan koefisien determinasi sebesar 0,468. Artinya variabel pelaksanan fungsi kepla madrasah memberikan hubungan sebesar $46,8 \%$ dengan variabel kinerja guruMTsN di kabupaten Solok dalam keadaan konstan. Besar koefisien korelasi $\mathrm{X}_{2}$ dengan $\mathrm{Y}$ pada saat $\mathrm{X}_{1}$ dikontrol adalah sebesar 0.757 dan koefisien determinasi sebesar 0,573. Artinya bahwa variabel iklim organisasi memberikan hubungan sebesar 57,3\% dengan variabel kinerja guru MTsN di kabupaten Solok dalam keadaan konstan.

\section{TEMUAN PENELITIAN}

Hasil analisis ini menunjukkan besarnya sumbangan murni yang diberikan oleh masing-masing variabel bebas dengan variabel kinerja guru MTs $\mathrm{N}$ di kabupaten Solok positif dengan meningkatnya variabel kinerja guru MTsN di kabupaten Solok.Analisis data menunjukkan bahwa kinerja guru dipengaruhi oleh pelaksanaan fungsi kepala madrasah dan iklim organisasi baik secara sendirisendiri maupun bersama-sama. Pelaksanaan fungsi kepala madrasah dan iklim organisasi merupakan dua faktor yang sangat penting karena dapat mempengaruhi kinerja guru. Pelaksanaan fungsi kepala madrasah yang dilakukan oleh kepala sekolah dengan baik dan didukung oleh iklim oganisasi yang baik pula maka akan dapat lebih meningkatkan kinerja guru dalam melaksanakan tugasnya.

\section{PENUTUP}

Berdasarkan data dan hasil analisis yang telah dipaparkan dapat ditarik kesimpulan 
sebagai berikut: Pelaksanaan fungsi kepemimpinan kepala Madrasah berkontribusi sangat signifikan terhadap kinerja guru MTsN di kabupaten Solok sebesar 46,8\%.Ini berarti $46,8 \%$ varian yang terjadi pada kinerja guru MTsN di kabupaten Solok merupakan kontribusi dari faktor pelaksanaan fungsi kepala madrasah.

Iklim organisasi berkontribusi sangat signifikan terhadap kinerja guru MTsN di kabupaten Solok sebesar 57,3\%. Ini berarti $57,5 \%$ varian yang terjadi pada kinerja guru MTsN di kabupaten Solok merupakan kontribusi dari faktor iklm organisasi. Secara simultan Pelaksanaan fungsi kepemimpinan kepala Madrasah dan iklim organisasi secara bersama-sama (simultan) berkontribusi sangat signifikan terhadap kinerja guru MTsN di kabupaten Solok sebesar 63,3\%. Hal ini menjelaskanbahwa upaya untuk meningkatkan kinerja guru dapat dilakukan melalui peningkatan pelaksanaan fungsi kepemimpinan kepala Madrasah bersamaan dengan upaya peningkatan iklim organisasi.

Temuan penelitian membuktikan bahwa kinerja kerja guru mempunyai hubungan yang signifikan dari pelaksanaan fungsi kepala madrasah dan iklim oeganisasi secara parsial maupun secara bersama-sama. Secara statistik pelaksanaan fungsi kepala madrasah dan iklim oeganisasiberkotribusi positif dengan kinerja guruMTsN di kabupaten Solok.Ini berarti bahwa kinerja guru dapat ditingkatkan melalui pelaksanaan fungsi kepemimpinan kepala madrasah dan iklim organisasi.

Untuk meningkatkan kinerja guru, dapat dilakukan dengan memperbaiki proses pembelajaran dalam kelas, melakukan pelatihan terhadap guru-guru terutama pelatihan yang berkaitan dengan strategi pembelajaran. Disamping itu perlu juga memberikan kebebasan kepada guru untuk berkreasi, mendorong para guru dalam mengelola proses belajar mengajar di kelas, memberikan beban kerja yang proporsional, dan memperkaya metode dan model pembelajaran.

Usaha untuk meningkatkan kedua variabel pelaksanaan fungsi kepemimpinan kepala madrasah dan iklim organisasi ini diharapkan dapat meningkatkan kinerja guru MTsN di kabupaten Solok, Dinas Pendidikan dan Kemenag mempunyai wewenang dan bertanggung jawab untuk membina para kepala sekolah dalam meningkatkan kualitas pelaksanaan fungsinya dan membina para guru untuk meningkatkan kompetensi dirinya agar berdampak kearah peningkatan kinerja.

Untuk meningkatkan kineja guru diiharapkan kepala madrasah dapat melaksanakan fungsinya sebagai kepala madrasah dengan baik, terutama pada indikator kepala madrasah sebagai pendidik, memperhatikan iklim organisasi madrasah yang dipimpinnya terutama pada indikator perubahan dan perbaikan, sehingga para guru dapat merasakan suasana yang kondusif dalam melaksanakan tugas seharihari, memberdayakan seluruh potensi yang ada, meningkatkan reputasi sekolah masa depan, menumbuhkembangkan potensi kepemimpinan tanpa mengorbankan pihak lain, dalam hal ini, kepemimpinan kepala madrasah hendaknya mampu mempengaruhi 
dirinya dan orang lain sehingga secara sukarela bekerja dan ikhlas mencapai tujuan bersama.

Kepada pihak yang berkepentingan atau yang terkait langsung dengan bidang pendidikan (khususnya Kementerian Agama kabupaten Solok) Agar lebih baik dalam menyeleksi pengangkatan kepala madrasah, agar kepala madrasah yang ditunjuk adalah seorang kepala madrasah yang betul-betul mampu untuk melaksanakan fungsinya sebagai seorang pimpinan, agar dalam membuat program kerja, kebijakan, dan pembinaan guru dimasa yang akan datang lebih memberikan kesempatan kepada guru untuk mengembangkan dirinya dalam rangka meningkatkan kinerja guru.

\section{KEPUSTAKAAN ACUAN}

Amstrong, M. And Baron, A Performance Management, The New Realities, Terjemahan, London: Institute of Personel and Development, 1998.

Departemen Agama RI, al-Hikmah, al-Qur'an dan Terjemahnya, Bandung: CV. Penerbit Diponegoro, 2011.

Djam'an Satori dkk., Profesi Keguruan, Jakarta: Universitas Terbuka, 2007.

Sondang P. Siagian, Manajemen Sumber Daya Manusia, Jakarta: Bumi Aksara, 2002. 